\title{
Specific $\mathbf{G}_{\mathbf{1}}-\mathbf{S}$ phase cell cycle block by beryllium as demonstrated by cytofluorometric analysis
}

\author{
David N. SKILLETER, Roger J. PRICE and Robert F. LEGG \\ MRC Toxicology Unit, Medical Research Council Laboratories, Woodmansterne Road, Carshalton, Surrey \\ SM5 4EF, U.K.
}

(Received 29 September 1983/Accepted 13 October 1983)

\begin{abstract}
Inhibition of cell division by beryllium $\left(\mathrm{Be}^{2+}\right)$ has been examined in synchronized cultures of a liver-derived cell line (BL9L cells) using cytofluorometric cell cycle analysis. Results show that a selective dose-related block of the $G_{1}-$ pre-S transition is produced, with other periods of the cell cycle appearing relatively insensitive.
\end{abstract}

The notional separation of the cell division cycle into the DNA synthetic phase $(S)$, the first gap $\left(G_{1}\right)$ between mitosis $(M)$ and $S$, and the second gap $\left(G_{2}\right)$ between $S$ and $M$, in addition to the concept of resting cells $\left(G_{0}\right)$, is well established (Howard \& Pelc, 1953; reviewed by Stein \& Baserga, 1972). Recent use of selective fluorescent stains to identify both the amount and structural form of DNA present in nuclei in conjugation with flow cytometry measurements has facilitated the routine and rapid analysis, with commercially available instruments, of the cell cycle into $G_{1}\left(G_{0}\right), S$ and $G_{2} / M$ phases (Darzynkiewicz et al., 1977; Gray et al., 1979). Accordingly the procedure of cytofluorometric cell cycle analysis has become extremely useful to study the effects of exogenous chemicals on the cell cycle, particularly in synchronized dividing cell culture systems.

A number of genotoxic or carcinogenic metals have been examined by cytofluorometric cell cycle analysis, and, for example, arsenic, nickel and cobalt have been shown to produce an $\mathrm{S}$ phase specific cell block (Costa et al., 1982), whereas chromium prolongs the $G_{2} / M$ phase (Bakke et al., 1982). Our interest has been concerned with the metallocarcinogen beryllium $\left(\mathrm{Be}^{2+}\right)$, which for some years has been known to inhibit both cell division of cultured cells (Chevremont \& Firket, 1951) and the process of DNA synthesis in hepatic cell regeneration (Witschi, 1970). Furthermore, indirect evidence, from time lapse cinematographic analysis, of an increase in cell interdivision time in $\mathrm{BeCl}_{2}$-treated fibroblasts (Absher et al., 1983) and the inhibition by $\mathrm{BeSO}_{4}$ of histone phosphorylation in regenerating liver (Kaser et al., 1980), have suggested that $\mathrm{Be}^{2+}$ may act by inhibition of the $G_{1}$ to $S$ phase. The purpose of the present investigation was to examine directly by cytofluorometric cell cycle analysis the effects of $\mathrm{Be}^{2+}$ on the synchronized division of a liver-derived cell line (BL9L) in vitro in order to determine the $\mathrm{Be}^{2+}$-susceptible cell cycle phase.

\section{Experimental \\ Culture and synchronization of cells}

Rat-liver-derived epithelial cells (BL9L) indistinguishable from the previously reported BL8L cell line (Judah et al., 1977) were used throughout as monolayer cultures on $100 \mathrm{~mm}$ plastic petri dishes. Cell synchrony was achieved by seeding $3 \times 10^{6}$ cells in $9 \mathrm{ml}$ of culture medium [Williams $\mathrm{E}$ medium (Flow Laboratories) containing $2 \mathrm{~mm}$-glutamine, $0.5 \%$ gentamycin and $5 \%(\mathrm{v} / \mathrm{v})$ foetal calf serum (Sera Lab)], followed by culture for 3 days at $37^{\circ} \mathrm{C}$ and pH 7.3 in a humidified atmosphere of $\mathrm{O}_{2} / \mathrm{CO}_{2}$ $(1: 19)$ to achieve a confluent monolayer (approx. $9 \times 10^{6}$ cells). At this stage cytofluorometric cell cycle analysis estimated $80-85 \%$ of cells to be in the $G_{1}\left(G_{0}\right)$ phase, $10-15 \%$ in $D$ phase and the remainder in $G_{2} / M$. Cells were dispersed by exposure to $10 \%$ trypsin (Flow Laboratories) in phosphatebuffered saline [Dulbecco A (Oxoid)] for $2 \mathrm{~min}$ at room temperature, followed by removal of the medium and incubation of the cells at $37^{\circ} \mathrm{C}$ for $8 \mathrm{~min}$ prior to elution from the dish by suspension in culture medium. Cells were then centrifuged at $350 \mathrm{~g}$ for $2 \mathrm{~min}$ and washed once with phosphate-buffered saline. Cells $\left(3 \times 10^{6}\right)$ were next subcultured in $9 \mathrm{ml}$ of serum-free culture medium for $4 \mathrm{~h}$ [during which time attachment occurs without multiplication (Temin et al., 1972)] followed by replacement in the normal culture medium (with $5 \%$ serum) containing any other additions, to initiate the cell division cycle. Under these conditions $S$ phase commenced at about 
$16 \mathrm{~h}$, and was maximal at $20 \mathrm{~h}(50-60 \%$ of cells). The greatest proportion of cells in the $G_{2} / M$ phase (15-20\%) was also observed at about $20 \mathrm{~h}$ and was followed by a gradual return of cells to $G_{1}\left(G_{0}\right)$ between $24 \mathrm{~h}$ and $72 \mathrm{~h}$.

\section{Cytofluorometric cell cycle analysis}

At the indicated times cells were removed from the culture dishes by the trypsinization procedure described above, prior to dispersion in $5 \mathrm{ml}$ of filtered $(0.22 \mu \mathrm{m})$ fluorochrome stain comprising $0.1 \%$ sodium citrate, $0.005 \%$ ethidium bromide (Sigma) and $0.1 \%$ Triton $\mathrm{X}-100$. To this suspension was added $0.25 \mathrm{ml}$ of $0.01 \%$ ribonuclease $A$ (Sigma) and the mixture was placed on ice for at least $10 \mathrm{~min}$ prior to cytofluorometric analysis. In principle the procedure involves passage of the fluorescently (ethidium bromide) labelled nuclei, derived from the cells, as a single stream through a suitable activating laser light source such that the fluorescent light emitted (which is proportional to DNA content) can be quantified. In the present studies nuclear DNA content was determined at an analysis rate of 1000 nuclei/s for a total of 20000 nuclei by use of an Ortho Cytofluorograf System 50-H model 2150 (Ortho Diagnostics Systems, Westwood, MA, U.S.A.) fitted with an argon ion laser. The fluorochrome was excited at $480 \mathrm{~nm}$ and the emission measured above $630 \mathrm{~nm}$. This instrument computes the data to present $G_{1}\left(G_{0}\right), S$ and $G_{2} / M$ cell cycle phases in the form of an integrated histogram from which percentage phase values can be calculated by using the Ortho program 'DNADISC'. This program also permits discrimination of doublets in the nuclear population.

\section{Additional procedures}

Beryllium uptake by cells was measured radiochemically in separate experiments using media containing ${ }^{7} \mathrm{BeSO}_{4} \quad(1-500 \mu \mathrm{M} ; 0.37 \mathrm{MBq} / \mu \mathrm{mol})$ according to procedures previously described (Skilleter \& Paine, 1979). Cell protein was estimated by the method of Markwell et al. (1978) and DNA synthesis by $\left[{ }^{3} \mathrm{H}\right]$ thymidine incorporation (Terasima \& Tolmach, 1963).

\section{Results and discussion}

Continuous exposure of synchronized BL9L cells to $50 \mu \mathrm{M}-\mathrm{BeSO}_{4}$ caused a marked inhibition of cell division. Fig. 1 illustrates that whereas the proportion of S-phase cells in controls increased from a starting level of $13-15 \%$ to about $55 \%$ at $20 \mathrm{~h}$, in the presence of $50 \mu \mathrm{M}-\mathrm{BeSO}_{4}$ a corresponding increase to only $20-23 \%$ was observed. At $24 \mathrm{~h}$ control cells showed a decrease of cells in S phase to $30-40 \%$, which continued for the next $48 \mathrm{~h}$ to $10-15 \%$ as the cells recycled to the status of $80-85 \%$ estimated to
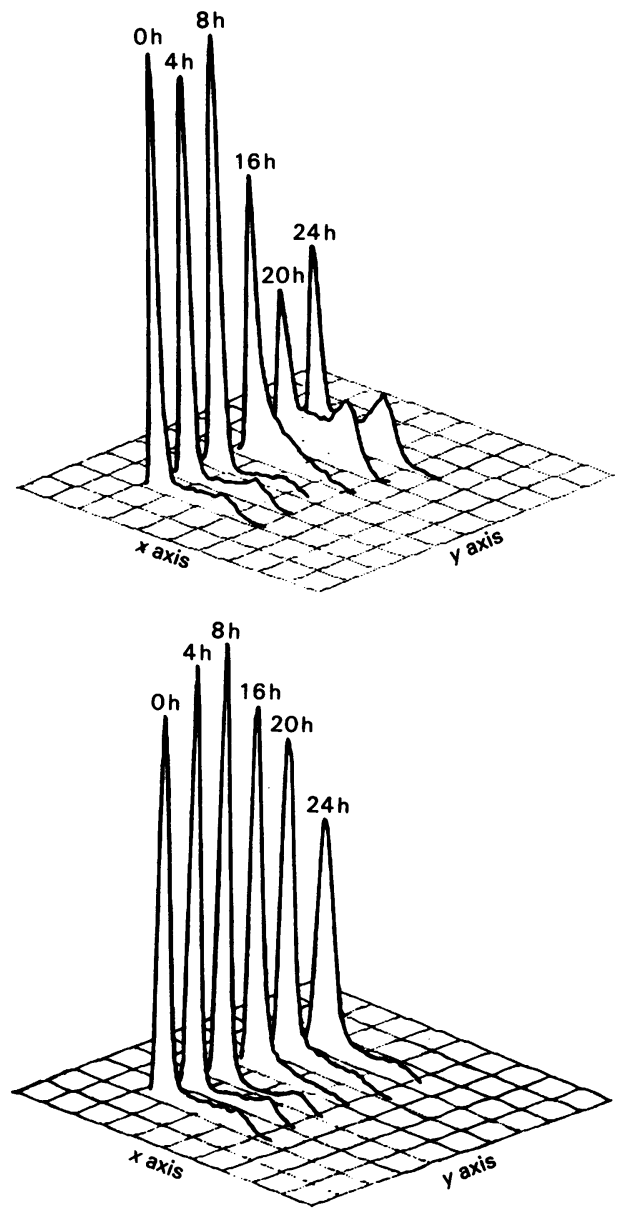

Fig. 1. Beryllium inhibition of cell division in vitro Monolayer cultures of BL9L cells were incubated in the absence $(a)$ or presence $(b)$ of $50 \mu \mathrm{M}-\mathrm{BeSO}_{4}$, then cytofluorometric cell cycle analysis was performed at the times indicated according to the procedure described in the Experimental section. Results are presented as a series of stacked histograms ( $y$ axis) each comprising the Cytofluorograf-computed data of the cell cycle analysis (DNA fluorescence) at each time point $\left[x\right.$ axis: initial peak, $G_{1}\left(G_{0}\right)$; intermediate region, $S$; second peak, $\left.G_{2} / M\right]$.

be in $\mathrm{G}_{1}\left(\mathrm{G}_{0}\right)$. During this period $\mathrm{Be}^{2+}$-treated cells also showed a decrease in the proportion of S-phase cells to about $9 \%$ but this was associated with detachment of $7 \%$ of the cells at $24 \mathrm{~h}$ and $34 \%$ at $72 \mathrm{~h}$. In the presence of $100 \mu \mathrm{M}-$ or $500 \mu \mathrm{M}-\mathrm{BeSO}_{4}$, complete impairment of cell division was observed but this resulted in the detachment of $23 \%$ and $40 \%$ respectively of the cells within $24 \mathrm{~h}$. These initial investigations therefore suggested that the pre-S phase was the most susceptible to $\mathrm{Be}^{2+}$ inhibition. 
Table 1. Sensitivity of $G_{1}-S$ phase of cell cycle to $B e^{2+}$ Monolayer cultures of BL9L cells, maintained for $24 \mathrm{~h}$, were exposed to $50 \mu \mathrm{M}-\mathrm{BeSO}_{4}$ for the periods indicated prior to cell cycle analysis at $24 \mathrm{~h}$ as detailed in Fig. 1.

Proportion of cells present at $24 \mathrm{~h}(\%)$ after exposure to $\mathrm{BeSO}_{4}$ for times indicated

$\begin{array}{cccccccc}\begin{array}{c}\text { Phase of } \\ \text { cell cycle }\end{array} & \text { Control }\left(\mathrm{no} \mathrm{Be}^{2+}\right) & 0-4 \mathrm{~h} & 0-24 \mathrm{~h} & 4-24 \mathrm{~h} & 8-24 \mathrm{~h} & 16-24 \mathrm{~h} & 20-24 \mathrm{~h} \\ \mathrm{G}_{1}\left(\mathrm{G}_{0}\right) & 50 & 82 & 80 & 67 & 54 & 56 & 51 \\ \mathrm{~S} & 36 & 14 & 14 & 19 & 29 & 34 & 33 \\ \mathrm{G}_{2} / \mathrm{M} & 14 & 4 & 6 & 14 & 17 & 10 & 16\end{array}$

Table 2. Dose-response relationship of $B e^{2+}$ inhibition of $G_{1}-S$ phase of cell cycle

Monolayer cultures of BL9L cells maintained for $24 \mathrm{~h}$ were exposed to various concentrations of $\mathrm{BeSO}_{4}(1-100 \mu \mathrm{M})$ for the first $0-4 \mathrm{~h}$ followed by subsequent incubation in $\mathrm{Be}^{2+}$-free media for $20 \mathrm{~h}$ prior to measurements of cell cycle analysis, cell $\mathrm{Be}^{2+}$ content and protein, or DNA synthesis $\left(\left[{ }^{3} \mathrm{H}\right]\right.$ thymidine added at change of medium) at $24 \mathrm{~h}$ as described in the Experimental section. Data for uptake are quoted as means \pm S.D. for four determinations. Values for relative cell protein are relative to protein at zero time assumed as 1.0.

\section{$\mathrm{Be}^{2+}$ uptake (nmol/mg of cell protein)}

Relative cell protein Inhibition of $G_{1}-S$ phase

Inhibition of DNA synthesis (\%)

\begin{tabular}{ccccccc}
\multicolumn{6}{c}{ Concentration of $\mathrm{BeSO}_{4}(\mu \mathrm{M})$ present during $0-4 \mathrm{~h}$} \\
\hline 0 & 1 & 5 & 10 & 20 & 50 & 100 \\
0 & $0.48 \pm 0.16$ & $1.12 \pm 0.41$ & $2.43 \pm 0.67$ & $3.72 \pm 1.01$ & $6.20 \pm 0.92$ & $9.28 \pm 0.81$ \\
2.24 & 2.25 & 2.27 & 2.24 & 2.02 & 1.63 & 1.36 \\
- & - & - & - & $-/+$ & + & + \\
0 & 0 & 0 & 0 & 15 & 64 & 96
\end{tabular}

To examine further the period(s) of the cell cycle most sensitive to $\mathrm{Be}^{2+}$, continuous exposure of cells to $50 \mu \mathrm{M}-\mathrm{BeSO}_{4}$ was compared with the addition of $50 \mu \mathrm{M}-\mathrm{BeSO}_{4}$ to the culture medium only for the periods $0-4 \mathrm{~h}, 4-24 \mathrm{~h}, 8-24 \mathrm{~h}, 16-24 \mathrm{~h}$ or $20-24 \mathrm{~h}$; for the remaining times cells were cultured in $\mathrm{Be}^{2+}$-free media. Cell cycle analysis at $24 \mathrm{~h}$ revealed that $\mathrm{Be}^{2+}$ inhibition was only observed if cells had been exposed to $\mathrm{BeSO}_{4}$ prior to $8 \mathrm{~h}$ incubation, after which no significant effects were seen (Table 1). More interestingly, it was noted that the critical exposure period was $0-4 \mathrm{~h}$, since incubation of cells in the presence of $\mathrm{Be}^{2+}$ at this stage was as effective as continuous exposure; addition of $\mathrm{BeSO}_{4}$ after $4 \mathrm{~h}$ being only partially effective (Table 1 ). These results indicated that $\mathrm{Be}^{2+}$ selectively inhibited the $\mathrm{G}_{1}-$ pre-S phase of the cell cycle.

Cellular uptake of $\mathrm{Be}^{2+}$ in the presence of a range of $\mathrm{BeSO}_{4}$ concentrations $(1-100 \mu \mathrm{M})$ was measured as ascertain the dose-response relationship for $\mathrm{BeSO}_{4}$ inhibition of cell division. Table 2 indicates that inhibition of cell division was difficult to detect after cells had accumulated less than about $4 \mathrm{nmol}$ of $\mathrm{Be} / \mathrm{mg}$ of cell protein, but was readily observed when cells had taken up above $6 \mathrm{nmol}$ of $\mathrm{Be} / \mathrm{mg}$ of cell protein. Assuming a value of $3 \times 10^{6}$ cells equivalent to $1 \mathrm{mg}$ of cell protein for this type of cell preparation (Skilleter \& Paine, 1979), the latter estimate corresponds to $2 \mathrm{nmol}$ of $\mathrm{Be} / 10^{6}$ cells, which has been previously calculated as the cell dose of $\mathrm{Be}^{2+}$ necessary to cause cytotoxicity to liver cells both in vivo (Skilleter \& Price, 1978) and in vitro (Skilleter \& Paine, 1979). Table 2 shows that the effects of $\mathrm{Be}^{2+}$ on cell division were also consistent with the inhibitory effects seen on the increase in total cell protein and DNA synthesis during the $24 \mathrm{~h}$ incubation period.

The studies described illustrate a $\mathrm{Be}^{2+}$ block in the $\mathrm{G}_{1}-\mathrm{S}$ phase of the cell cycle and imply there is no inhibition of the $S-G_{2} / M$ or $G_{2} / M-G_{1}\left(G_{0}\right)$ phases. It is known that both pinocytosis and phagocytosis of a variety of materials by cells is less during the $\mathrm{G}_{2} / \mathrm{M}$ than $\mathrm{G}_{1}$ phase (Riley \& Dean, 1978; Quintart et al., 1979; Berlin \& Oliver, 1980) and we have previously shown that $\mathrm{Be}$ is taken up by cells primarily by endocytosis (Skilleter \& Paine, 1979). Therefore, it was possible that the apparent lack of $\mathrm{Be}^{2+}$ effect on the $\mathrm{S}-\mathrm{G}_{1}$ phases might be due to a markedly decreased rate of $\mathrm{Be}^{2+}$ accumulation during this period. This suggestion had some support from the observation that in the presence of $50 \mu \mathrm{M}-\mathrm{BeSO}_{4}$, monolayer $\mathrm{Be}^{2+}$ uptake between either $16-20 \mathrm{~h}$ or $20-24 \mathrm{~h}$ was approx. $50 \%$ of that measured during $0-4 \mathrm{~h}$ (Table 3 ). However, during the same exposure periods, but in the presence of media containing $500 \mu \mathrm{M}-\mathrm{BeSO}_{4}$, more comparable levels of Be uptake were observed (Table 3), yet, no inhibition of the $S$ through $G_{2} / M$ to $G_{1}$ phases was apparent after addition of $500 \mu \mathrm{M}-\mathrm{BeSO}_{4}$ to the cells at $16 \mathrm{~h}$ (Fig. 2). It must therefore be concluded that, 
Table 3. Comparison of $\mathrm{Be}^{2+}$ uptake by cells at different times during cell cycle

Monolayer cultures of BL9L cells were incubated in the presence of either 50 or $500 \mu \mathrm{M}-\mathrm{BeSO}_{4}$ for the periods indicated prior to measurement of cellular $\mathrm{Be}^{2+}$ content as described in the Experimental section. Data are quoted as means \pm S.D. for four determinations. Values in parentheses are nmol of $\mathrm{Be} / \mathrm{mg}$ of cell protein.

\begin{tabular}{|c|c|c|c|}
\hline \multirow{2}{*}{$\begin{array}{c}\text { Concentration } \\
\text { of } \mathrm{BeSO}_{4} \\
\text { present }(\mu \mathrm{M})\end{array}$} & \multicolumn{3}{|c|}{$\begin{array}{l}\text { Uptake of } \mathrm{Be}^{2+}(\mathrm{nmol}) \text { by monolayer at } \\
\text { the times indicated }\end{array}$} \\
\hline & $0-4$ & $16-20 \mathrm{~h}$ & $4 \mathrm{~h}$ \\
\hline 50 & $\begin{array}{r}2.34 \pm \\
(6.2\end{array}$ & $\begin{aligned} 1.22 \\
(1 .\end{aligned}$ & $\begin{array}{l}0.2 \\
7)\end{array}$ \\
\hline 500 & $\begin{array}{l}3.10 \pm 0.3 \\
(5.89)\end{array}$ & $\begin{array}{l}4 \cdot 13 \pm 0.4 \\
\quad(3.86)\end{array}$ & $\begin{array}{l}5.88 \pm 0.4 \\
(4.67)\end{array}$ \\
\hline
\end{tabular}

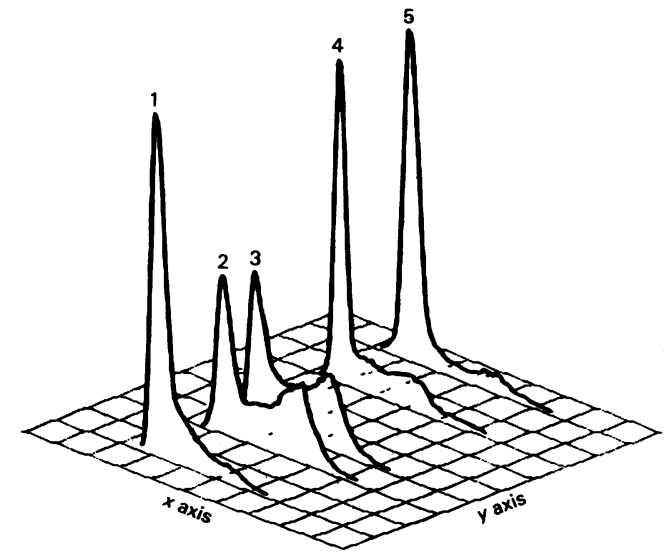

Fig. 2. Insensitivity of $G_{2} / M$ phase of cell cycle to $B e^{2+}$ Cell cycle analyses were performed on monolayer cultures of BL9L cells as detailed in Fig. 1 after incubation under the following conditions. Samples 1,2 and 4 : incubation in $\mathrm{Be}^{2+}$-free media for $16 \mathrm{~h}$, $24 \mathrm{~h}$ and $48 \mathrm{~h}$ respectively. Samples 3 and 5: incubation in the presence of $500 \mu \mathrm{M}-\mathrm{BeSO}_{4}$, added at $16 \mathrm{~h}$ and analysed at $24 \mathrm{~h}$ and $48 \mathrm{~h}$ respectively.

during the periods of DNA synthesis and mitosis, although Be is accumulated by BL9L cells it is either not released intracellularly to exert its effects, or that these phases of the cell cycle are relatively insensitive to the inhibitory action of the metal ion.

Reasons for the sensitivity of the $G_{1}$-pre-S phase to $\mathrm{Be}^{2+}$ cannot be provided from data presented in the present paper. However, previous studies have shown that $\mathrm{BeSO}_{4}$ can inhibit nuclear protein phosphorylation processes (Kaser et al., 1980; Williams \& Skilleter, 1983) and $\mathrm{Be}^{2+}$ has a strong affinity for binding to non-histone nuclear proteins (Parker \& Stevens, 1979). It is suggested, therefore, that since non-histone proteins are actively and selectively phosphorylated during the first few hours of the $G_{1}-S$ phase of the cell cycle (reviewed by Stein \& Baserga, 1972; Ord \& Stocken, 1980) it could be the inhibition of these phosphorylation processes that is responsible for the observed $\mathrm{Be}^{2+}$ inhibition of cell division.

We thank Andrew W. R. Payne, Institute of Cancer Research, Sutton, U.K. for provision of the 'stacked histogram' program used to present some of our results.

\section{References}

Absher, M., Sylwester, D. \& Hart, B. A. (1983) Environ. Res. 30, 34-43

Bakke, O., Jakobsen, K. \& Eik-Nes, K. B. (1982) Proc. Comb. Int. Conf. Anal. Cytol./Int. Symp. Flow Cytometry 6th, 9

Berlin, R. A. \& Oliver, J. M. (1980) J. Cell Biol. 85, 660-671

Chevremont, M. \& Firket, H. (1951) Nature (London) 167,772

Costa, M., Cantoni, O., de Mars, M. \& Swartzendruber, D. E. (1982) Res. Commun. Chem. Pathol. Pharmacol. 38, 405-419

Darzynkiewicz, Z., Traganos, F., Sharpless, T. K. \& Melamed, M. R. (1977) Cancer Res. 37, 4635-4650

Gray, J. W., Dean, P. N. \& Mendelsohn, M. L. (1979) (eds), Flow Cytometry and Sorting, pp. 383-407, John Wiley, New York

Howard, A. \& Pelc, S. R. (1953) Heredity Suppl. 6, 261-282

Judah, D. J., Legg, R. F. \& Neal, G. E. (1977) Nature (London) 265, 343-345

Kaser, M. R., Ord, M. G. \& Stocken, L. A. (1980) Biochem. Int. 1, 148-154

Markwell, M. A., Haas, S. M., Bieber, L. L. \& Tolbert, N. E. (1978) Anal. Biochem. 87, 206-210

Ord, M. G. \& Stocken, L. A. (1980) Biochem. Soc. Trans. 8, 759-766

Parker, V. H. \& Stevens, C. (1979) Chem. Biol. Interact. 26, 167-177

Quintart, J., Leroy-Honyet, M., Troulet, A. \& Baudhuin, P. (1979) J. Cell Biol. 82, 644-653

Riley, P. A. \& Dean, R. T. (1978) Exp. Cell Biol. 46, 367-373

Skilleter, D. N. \& Paine, A. J. (1979) Chem. Biol. Interact. 24, 19-33

Skilleter, D. N. \& Price, R. J. (1978) Chem. Biol. Interact. 20, 383-396

Stein, G. \& Baserga, R. (1972) Adv. Cancer Res. 15, 287-330

Temin, H. M., Pierson, R. W., Jr. \& Dulak, N. C. (1972) in Growth, Nutrition and Metabolism of Cells in Culture (Rothblat, G. H. \& Cristofalo, V. J., eds.), vol. 1, pp. 49-81, Academic Press

Terasima, T. \& Tolmach, L. J. (1963) Exp. Cell Res. 30, 344-362

Williams, B. E. \& Skilleter, D. N. (1983) Biosci. Rep. 3, 955-962

Witschi, H. P. (1970) Biochem. J. 120, 623-634 